\title{
Conflict or cooperation? Social capital as a power resource and conflict mitigation strategy in timber operations in Ghana's off-reserve forest areas
}

\author{
Mirjam A. F. Ros-Tonen ${ }^{1}$ and Mercy Derkyi ${ }^{2}$
}

\begin{abstract}
Conflicts over forests and trees threaten the sustainability of the resource base. The nature and causes of such conflicts have been documented, but little is known about factors that determine whether interactions result in conflict or cooperation. Particularly, the role of social capital has been underexposed, with existing studies focusing mainly on networks, and less on the role of norms, trust, and reciprocity in conflict mitigation. Our case study addresses these gaps, asking what factors determine whether interactions about timber resources in Ghana's off-reserve forest areas result in conflict or cooperation. Off-reserve areas, which are mosaics of forest, fallow, and farmland patches, contribute significantly to timber for domestic and export markets, despite a rapidly declining resource base since the 2000s. Conflicts over legally required social responsibility agreements and inadequate compensation for crop damage abound, but, in rare cases, peaceful cooperation exists. Based on a literature review, document analysis, key respondent interviews, semistructured interviews, and focus groups, we found that interactions between actors are shaped by a complex mix of socioeconomic, social, orientational, and institutional power resources that actors mobilize to negotiate access to increasingly scarce timber resources and their benefits. Socioeconomic power resources initially determine whether a cooperative relationship between timber operators and communities can be established, but elements of social capital (connectedness, norms, trustworthiness, and reciprocity) determine the further course of the interaction patterns. Communities thereby rely primarily on bonding social capital because their bridging capital is practically absent and their linking capital is limited to people who are potential conflict partners. We conclude that conflicts in forested landscapes go beyond competing claims and benefit sharing, and that norms, trustworthiness, and reciprocity are at least as important dimensions of social capital as networks. This finding implies that more attention is needed toward the cultural context in which interactions are embedded.
\end{abstract}

Key Words: conflict and cooperation; forestry; Ghana; multifunctional landscapes; natural resource conflicts; norms; power resources; social capital; timber; trustworthiness

\section{INTRODUCTION}

Conflicts in tropical forest areas undermine livelihoods and the sustainability of the resource base (Mola-Yudego and Gritten 2010, Gritten et al. 2013, Derkyi et al. 2014, Leach and Scoones 2015). They occur not only in contiguous forest areas, but even more so in multifunctional landscapes where timber exploitation occurs next to agricultural and other economic activities.

In Ghana, the Forest and Wildlife Law refers to multifunctional landscapes as off-reserve forest areas: patches of forest, fallow, and farmland (Bih 2006). They differ legally from forest reserves, which are permanent forest estates encompassing different management regimes (conservation, timber production, and reforestation) under the jurisdiction of the Forestry Commission (FC). Conflicts in forest reserves revolve mainly around activities legally defined as illegal: chainsaw logging (Hansen and Treue 2009, Marfo 2010), galamsey (small-scale mining without a permit; Akpalu and Parks 2007, Hirons 2014), the extraction of nontimber forest products for trade without a permit, and farming beyond "admitted farms" that were allowed because they already existed prior to the gazetting of forest reserves (Derkyi 2012, Derkyi et al. 2014). In off-reserve areas, forest and tree conflicts are mostly related to the exploitation of timber trees on farms and the sharing of associated benefits and risks (Marfo and Schanz 2009, Marfo et al. 2012, Derkyi et al. 2014).

Despite ample documentation of forest and tree conflicts, much less is known about the factors that determine whether interactions result in conflict or cooperation (Ratner et al. 2013) and what role social capital plays in this respect. Literature usually focuses on competing claims and distributive issues as conflict sources (Table 1), whereas social capital literature tends to focus on the role of networks in conflict and natural resource management (e.g., Pretty 2003, Njuki et al. 2008, Marín et al. 2012; Barnes-Mauthe et al. 2015) rather than on norms, trust, and reciprocity. We address these gaps by revisiting a case of a conflict-free timber operation in an off-reserve area in Ghana described in earlier work (Derkyi 2012). That study suggested that building social capital was crucial in explaining the absence of conflict. Here, we aim to provide deeper insights by asking: What factors determine whether interactions about timber resources in Ghana's off-reserve forest areas result in conflict or cooperation? Insights into these factors are becoming increasingly important considering the growing complexity of stakeholder configurations in value chain relations and the governance of forested landscapes, potentially resulting in conflicts because of diverging interests and power positions (Ros-Tonen et al. 2018).

After elaborating the conceptual framework used here, we present the methodology. In the results, we analyze how power resources are deployed to negotiate access to increasingly scarce timber resources and their benefits. In the discussion, we position the case in the broader debate on natural resource conflicts and the importance of social capital in conflict mitigation. To conclude, we synthesize the findings and indicate implications and suggestions for further research.

${ }^{1}$ University of Amsterdam, Department of Geography, Planning and International Development Studies, ${ }^{2}$ University of Energy and Natural Resources, Department of Forest Science and Centre for Climate Change and Gender Studies (3CGS), Sunyani, Ghana 
Table 1. Categorization of forest conflicts. Sources: Compiled from Yasmi et al. (2006), Vedeld et al. (2012), Eckerberg and Sandström (2013), Gritten et al. (2013), and Derkyi et al. (2014).

\begin{tabular}{ll}
\hline \hline Major cause of conflict & Conflict type \\
\hline Contested values & Biodiversity conservation vs. productive use \\
& Indigenous rights \\
& Implementation of forest policies (e.g., "Reducing emissions from deforestation and forest degradation", \\
& {$[$ REDD+], policies leading to exclusion of forest users) } \\
& Nonforestry productive uses (e.g., agriculture, mining) vs. forestry \\
Competing resource claims & Illegal forest use (logging, nontimber forest products, herding, farming) \\
& Local population and civil society organizations resisting forestry operations, plantation development, or \\
& dam building \\
& Tenure conflicts \\
Conflicts about unequal benefit sharing and compensation payments
\end{tabular}

\section{ANALYTICAL FRAMEWORK}

\section{The action arena of conflict and cooperation}

Following Ratner et al.'s (2013) institutional analysis and development model (see also Hellin et al. 2018), we envision offreserve timber operations as an action arena. This arena is the configuration of actors, resources, rules, and regulations as well as interaction patterns that encompass conflict issues, negotiations, and conflict management. The context comprises resources, users, and governance arrangements. Key in the Ratner et al. (2013) model are the distinction between conflict and cooperation, and what factors determine the outcome in either of the two. We thereby define conflicts as "perceived or actual opposing or competing needs, values and interests between two or more parties related to the allocation, access, ownership or utilization of a resource" (Derkyi et al. 2014:286). Inherent in this definition is that forest conflicts usually revolve around contested values, competing resource claims, and distributive issues between stakeholders in different power positions (Marfo 2006, Derkyi 2012, Gritten et al. 2013; Table 1). These conflicts may differ in scale from household to local, regional, and global (Buckles and Rusnak 1999). Here, we focus on the local scale, in which a further distinction can be made in conflicts between households (intracommunity conflicts), between communities (intercommunity conflicts), and between communities and external actors (supracommunity conflicts; Sanginga et al. 2007). We focus on the latter, and more specifically, on conflicts and cooperation between communities and timber operators.

Cooperation, as the "mirror image" of conflict, has received much less attention in the literature than conflict and is generally less precisely defined. It is often loosely used in its literal meaning of "working together" (Bavinck et al. 2014). As we will show, it is equally a process that involves negotiation and setting the terms of working together.

We refine Ratner et al.'s (2013) model in three ways. First, following Marfo (2006), we acknowledge that resources, actors, and rules and regulations can be turned into power resources that actors mobilize to influence (potential) conflict partners and get what they want, e.g., access to scarce resources or monetary compensation for exploiting trees on farmland. Drawing from Hermens (1999), Marfo (2006) classed these power resources as socioeconomic (material and economic benefits), social (different kinds of networks), orientational (strategic and cultural framing, information and knowledge, cultural symbols and beliefs, threats and sanctions), and institutional (e.g., statutory and customary legitimacy and laws). These power resources shape the patterns of interactions. Second, we add conflict management strategies to the patterns of interaction (labeled power strategies in Marfo 2006). These are used as tactics in conflicts and negotiations, ranging from avoidance to force, with persuasive and manipulative bargaining, mediation, arbitration, and litigation in between (Fig. 1). Third, we further elaborate on Marfo's (2006) social power resources using literature on social capital in natural resource management by Pretty and colleagues (Pretty and Ward 2001, Pretty 2003, Pretty and Smith 2004), who define social capital as relations among individuals or institutions bonded by connectedness in networks and groups, trust, common rules and norms, and reciprocity. This body of literature is rooted in the work of Putnam (1993) and Coleman (1998), which was popularized by Putnam (2000).

Trust that individuals act as expected is key to cooperation and largely depends on past experience, a person's reputation, and the sanctions for breaking a person's trust (Lyon 2000). We prefer the word "trustworthiness" because it better covers the Twi word for gyedi, which is (also) understood as "confidence, knowledge of a person's ability, belief, and faith" (Lyon 2000:664). Norms define what is seen as desirable or unacceptable behavior within a group (Lyon 2000, Pretty and Ward 2001, Pretty 2003). Reciprocity can be specific ("simultaneous exchanges of items of roughly equal value") or diffuse ("a continuing relationship of exchange that at any given time may be unrequited, but over time is repaid and balanced"; Pretty and Ward 2001:211). Both norms and reciprocity contribute to trust (Pretty and Ward 2001).

Social power resources can be mobilized through connectedness within, between, and beyond local communities, equivalent to bonding, bridging, and linking social capital, respectively. Bonding capital is the social cohesion within a community based on local ties, trust, and shared moral values among people of similar ethnicity, social status, and location (Pretty 2003, Sanginga et al. 2007). Bridging social capital refers to network ties between more distant groups operating at similar levels (e.g., between communities), and linking capital refers to network ties between groups and institutions across different situations and levels (Putnam 2000, Pretty 2003, Pretty and Smith 2004). Recent social capital literature emphasizes the importance of bridging and linking networks for natural resource management and 
Fig. 1. Analytical framework for the study. The framework draws from Ratner et al. (2013) for context, action arena (with resources, actors, rules and regulations, and patterns of interaction), and outcomes; from Marfo (2006) for power resources; and from Lyon (2000), Pretty and Ward (2001), Pretty (2003) for components of social capital. Further operationalization of socioeconomic and social capital power resources resulted from a hybrid combination of deductive and inductive coding. Norms are separated from rules, which are analyzed as a separate part of the action arena, following Ratner et al. (2013).

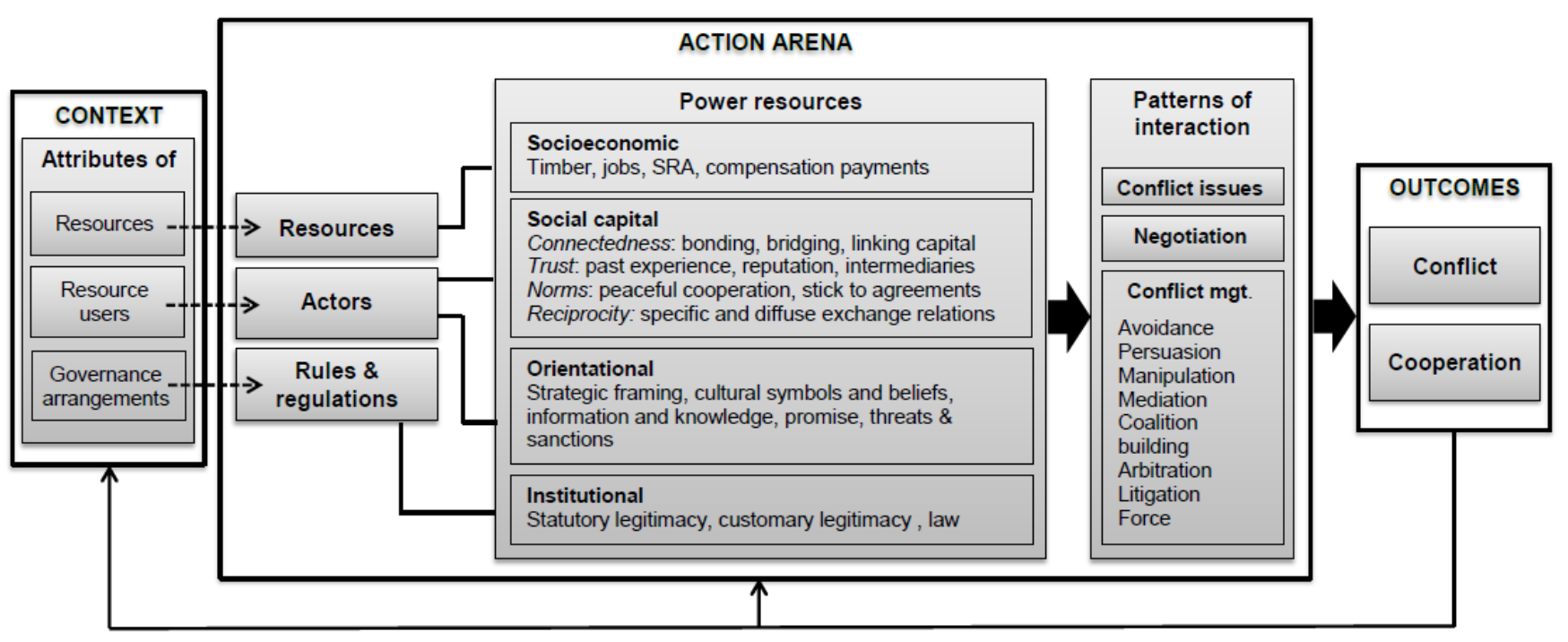

environmental governance (e.g., Bodin and Crona 2009, BarnesMauthe et al. 2015). In the Ghanaian context, particularly important are traditional networks, bonded by chiefs and elders; corporate networks (e.g., between cocoa farmers and a purchasing clerk affiliated to a buying company or between a timber operator and a local "tree hunter"); and networks between family and friends (Marfo 2006, Derkyi 2012, Kooijmans 2016).

We hypothesize that the way in which power resources are mobilized and deployed affects the patterns of interaction in conflicts, negotiations, and conflict management, as well as their outcome in terms of either conflict or cooperation (Fig. 1). It has been argued that, in particular, connectedness and trust facilitate cooperation and conflict resolution (Woolcock and Narayan 2000, Pretty 2003, Pretty and Smith 2004, Bodin and Crona 2008). We argue that, in particular, adherence to local norms, taboos, and cultural values are key factors in determining whether patterns of interaction result in conflict or cooperation.

\section{METHODS}

\section{Study sites}

Research was carried out in two study communities bordering the Tano-Offin forest reserve in the Ashanti Region of Ghana. The communities both fall under Nkawie Forest District and are administratively part of Atwima Mponua District (Fig. 2). Awisasu, with 565 inhabitants in 2016 (Atwima Mponua District Assembly, personal communication) was part of a broader study on forest conflicts in and around the Tano-Offin forest reserve (Derkyi 2012), then marked by conflict-free cooperation. It was revisited in April 2018 to record the evolution of the cooperation scenario since that time. Debra Camp (697 inhabitants) was chosen for comparison because no timber operations were ongoing at the original study site. Both communities belong to two stools: the Nyinahin and Nkawie Panin Stools. The Ghana Constitution recognizes the stool as the customary land owner who provides access to farming land to inhabitants of communities through the chiefs or family heads (Kasanga 2003:144).

Fig. 2. Map of the study communities Awisasu and Debra Camp bordering Tano-Offin Forest Reserve, Ghana.

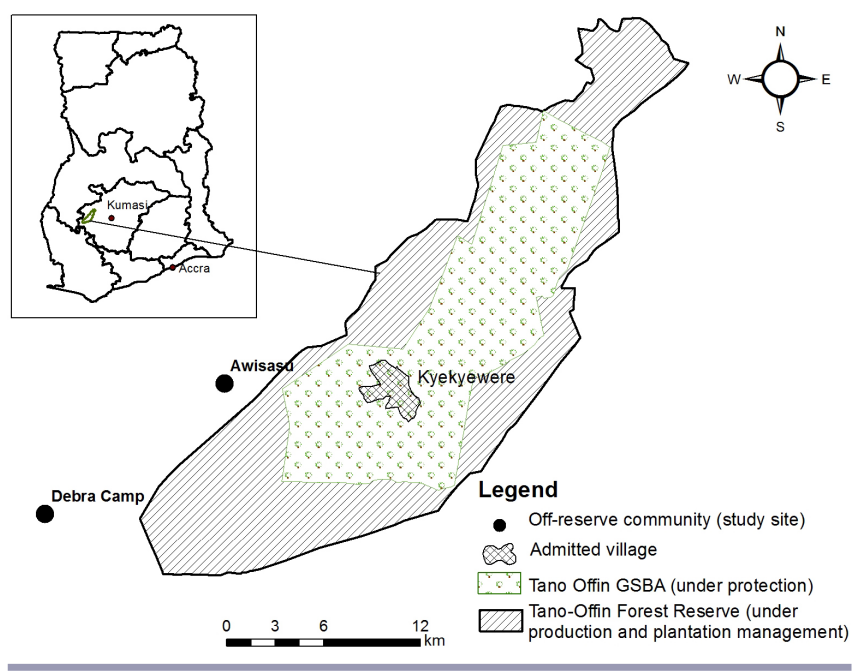

Awisasu has one chief for each stool landowner, whereas Debra Camp has only one chief and council, representing both. The communities represent a typical community in southern Ghana, 
with farming being the dominant occupation, and Christianity prevailing. Islam and traditional religions are in the minority ( $\leq$ $5 \%$ ). It should be noted that the term "community" is used here in the sense of "village," as is common in Ghana, and should not be taken as treating it a priori as a homogenous entity (see Discussion). However, according to the Atwima Mponua District Assembly (AMDA 2014:25), "the level of communal spirit in the District is very high."

\section{Data collection}

Data collection methods employed between 2008 and 2010 comprised familiarization visits, key respondent interviews with community representatives and government officials, a telephone interview with the timber operator, semistructured interviews with 17 farmers, a focus group with 45 community members, and a validation meeting involving 36 community members. The focus group and a telephone interview with timber contractors were focused on potential sources of conflict and factors that had facilitated cooperation. Topics discussed in the community meeting included livelihoods, prevailing conflicts over natural resources, and conflict management strategies employed. Key respondent interviews focusing on mediation in crop damage compensation negotiations and the agencies' roles in off-reserve tree management were held with officials of the District Forest Services Division (FSD), the District Ministry of Food and Agriculture, and the Land Valuation Division of the Land Commission of Ghana. The semistructured interviews with famers centered on types of timber trees on farm or fallow lands, year of harvest, and compensation payments for trees felled by the timber operator. Other items included land and tree tenure and types of cash and food crops on farm and fallow lands.

A community meeting was organized in Awisasu in 2018 with 51 males and 15 females, all farmers between 20 and 90 years of age. In Debra Camp, a focus group discussion (FGD) was organized with 22 males and six females, also all farmers, ranging in age from 25 to 75 years old. Key respondent interviews were held with an official of the FSD of the FC, a forest guard, and staff of the Resource Management Support Centre of the FC in Kumasi. Another telephone interview was held with the timber operator active in Awisasu from 2009-2015, focusing on his perception of the cooperation and his strategy of mobilizing power resources.

\section{Data analysis}

We used preset codes derived from the conceptual framework and research questions, and emergent codes covering recurrent issues, to code documents and transcriptions of community meetings and interviews. Quotations with similar codes were put together and linked to dimensions of power resources and social capital, arranging them under themes such as connectedness, norms, laws and regulations, etc. Triangulation through the use of mixed methods, respondent validation, and literature review showed high internal validity (consistent alignment of observations with theoretical ideas) and external validity (generalizability). Internal reliability or interobserver consistency was ensured through constant interaction among the researchers and research assistants. Transparency about data collection and processing ensures external reliability (replicability) of the study.

\section{RESULTS}

Following the conceptual framework, we first analyze how the context shapes the configuration of resources, actors, and rules and regulations. Second, we analyze how actors transform and use these contextual elements as power resources to negotiate access to timber trees and their benefits. Third, we look at conflict issues and management strategies as interaction patterns.

\section{Context: resources, users, and governance arrangements}

\section{Resources}

Off-reserve areas are an important component of Ghana's natural resource base, providing timber, agricultural livelihoods, and sites for plantation development (Kyereh et al. 2009). Valuable timber tree species still occur, especially on cocoa farms and fallows (Hansen and Treue 2009). With a timber harvest of $321,425 \mathrm{~m}^{3}$ in 2014 (MLNR 2016a), off-reserve areas contribute approximately one-third to the timber trade, which is a substantial portion, but much less than the estimated $80 \%$ in the 1990s (Marfo et al. 2012, Oduro et al. 2018). Atwima Mponua District is rich in commercial tree species such as wawa (Triplochiton scleroxylon), sapele or edinam (Entandrophragma cylindricum), esa (Celtis zenkeri Engl.), and asanfena or akata (Aningeria spp.; AMDA 2014; http://www.ghanatimber.org/species.php). Species harvested from the interviewees' farms include onyina (Ceiba pentrandra), ofram (Terminalia superba), and kyen-kyen (Antiaris spp.). Between 2 and 17 (average 9) trees were harvested per farm in Awisasu during the six-year operation period from 2009-2015 (Derkyi 2012).

\section{Users}

Farmers and timber operators are the main resource users in offreserve areas. Inhabitants of the study sites live mainly off agriculture. All interviewed farmers cultivated cocoa as a cash crop, and plantain, cassava, and cocoyam as food crops. Some farmers grow vegetables such as okra, pepper, tomatoes, and garden egg (a type of eggplant), while some rear livestock for domestic and commercial purposes. Farmers manage off-reserve timber resources by tending and nurturing saplings and trees of species that have value to them on farmland and, if needed, by protecting timber trees against fire outbreaks.

Timber operators include holders of legal Timber Utilization Contracts and other harvesting permits, as well as illegal chainsaw operators (in Ghana, on-the-spot timber processing with a chainsaw is prohibited). Only legal timber operators pay a stumpage fee (royalties) for the trees to be harvested; chainsaw operators make individual deals with chiefs and farmers.

The FSD of the FC is tasked with allocating timber rights to timber operators and occasionally mediating conflicts over crop damage and negotiations over social responsibility agreements (SRAs). In some districts, the latter role is performed by the District Assembly.

The Administrator of Stool Land is responsible for disbursing royalties among beneficiaries. Revenues from off-reserve timber constitute a significant funding source for District Assemblies and stools without on-reserve production forest or minerals (Kyereh et al. 2009). The Constitution of Ghana and derived acts and regulations determine that $50 \%$ of the royalties goes to the FSD, $24.75 \%$ to the District Assembly, $5 \%$ to the Administrator of Stool Land, $11.25 \%$ to the Stool, and $9 \%$ to the traditional authorities (chief and elders) as custodians of land on behalf of the community (Appendix 1). 


\section{Governance arrangements}

Existing tenure and benefit-sharing arrangements are common sources of conflict in Ghana's off-reserve areas, mainly because of the separation between rights to trees and land ownership (Amanor 2005). Farmers lost their rights to timber resources, first, through the 1962 Concession Acts, which vested the rights to all naturally regenerated trees in the State (i.e., the FC) and, second, through the ban on processing logs into forest products using chainsaws (L.I. 1649 of 1998; Amanor 2005). Individual farmers are only considered the owner of trees that they planted themselves, and hence are only allowed to cut planted trees. Only community organizations, nongovernmental organizations, or District Assemblies can occasionally apply for a permit, formerly referred to as a Timber Utilization Permit, to cut a few trees for social or community development purposes, but these cannot be sold (see Appendix 2).

Prevailing arrangements are in transition because of a Strategic Direction (4.1b) in the 2012 Forest and Wildlife policy that aims to create a firmer legal basis for improved benefits and tree tenure security for communities and individual farmers. Basically, the legal provisions under the old policy still prevail (Appendix 2). The system of allocating felling rights for a five-year period to timber operators through Timber Utilization Contracts in return for stumpage fees (royalties) is currently on hold after attempts to allocate timber harvesting rights through a competitive bidding process (Valerie Fumey Nassah, personal commnication, June 2018). Timber operators currently need to apply for a harvesting permit at the district offices of the FSD of the FC, a lengthy procedure that goes via regional offices to the FC headquarters in Accra (Valerie Fumey Nassah, personal commnication, June 2018). The stumpage fees are meant to provide returns to the landowner and to "contribute to the cost of forest management and timber regulation" (L.I. 1721 Timber Resources Management [Amendment]). The technical wing of the FC, the Resource Management Support Centre in Kumasi, together with the FSD and the Ministry of Land and Natural Resources (MLNR), are piloting a program to register all planted and naturally occurring trees on farms in a database as a basis for a new benefit-sharing framework in the near future that compensates farmers for tending trees on their land (MLNR 2016b; Valerie Fumey Nassah, RMSC, personal commnication, March 2018).

Currently, inhabitants of off-reserve areas are only entitled to a Social Responsibility Agreement (SRA) worth minimally 5\% of stumpage fees for "amenities, services or benefits" (e.g., contributions to school buildings, boreholes, etc.) and payments to compensate for crop damage (Forestry Commission 1998, section 3; Appendix 1).

\section{Power resources and their use in negotiations over timber and benefits}

Socioeconomic power resources

Socioeconomic power resources comprise timber for the operator, SRA arrangements for the communities, employment for youth, and compensation payments for farmers. The negotiations usually start with SRA arrangements, and none of the communities had disagreement about these arrangements. The SRA is generally used for community development:

The Chief and his elders, unit committee members, and two FSD officials met with the timber operators. They paid an amount of GHC 9200 in cash. The majority decided that it will be used to build an extra classroom block. - FGD Awisasu, April 2018 (1 GHC = USD 0.23 at time of the interview).

Everybody in the community does benefit [from the $S R A]$ since the money is usually used for community development. (...) Everyone is happy with the outcome. GHC 1000 will be used to pay the debt of land that was used to build the community clinic some years ago, 500 GHC to fix an electric meter in the clinic which is currently not having light, and 500 GHC to buy roofing sheets for the community toilet. - FGD Debra Camp, April 2018.

In addition to the SRA, it is deemed important to create youth employment, and this is used as a power resource to prevent conflicts.

You need to employ the youth for buy-in of the people. These youngsters often have a lot of influence in the community; it is always the youths that cause problems and hinder the progress of your work through demonstrations and the like. Having one or more youths employed minimizes such incidences and makes the community members accept you as part of the system. Interview with timber operator \#2, May 2018.

In contrast to the SRA, negotiations about compensation payments are on an individual basis and usually without witnesses present. Prices paid depend only partly on actual damage incurred, but are calculated based on the crops grown (cocoa fetching a higher compensation than food crops); location of the timber operation (fallow or farmland); and size, number, and quality of trees. There is no guidance from the MLNR, FC, or Ministry of Food and Agriculture in assessing crop damage or relating the compensation payments to specific tree and crop species (what farmers would prefer). The amounts paid are at the discretion of the timber operator and seem to be location specific, with prices between GHC 20 and 60 per tree in Awisasu and between GHC 100 and 200 per tree in Debra Camp. Compensation payments are sometimes negotiated before the operation and sometimes after, with no specific pattern prevailing. In the study communities, conflicts seemed to occur in rare cases when an agreement could not be reached, damage compensation was not paid, or trees were extracted without the farmer's consent. In the words of a timber operator:

I never oppose the farmers; we negotiate and agree on a specific price. - Interview with timber operator \#2, May 2018.

Both parties apparently know the margins and negotiate accordingly, with conflicts arising only if either party crosses these margins.

Once I was called for a conflict between a farmer and timber operator about crop damage compensation. It was later resolved; we found out that the amount the farmer was requesting for a tree was too much. - Interview with FSD Official, Nkawie Forest District, April 2018.

Despite the permit that gives timber operators the legal right to fell naturally regenerated timber trees on farmers' land, not all farmers believe that negotiation power is unequally distributed. 
The farmer has the power because the timber operator cannot harvest the trees without his consent. - Farmer from Awisasu, FGD April 2018.

Here, the farmer decides on the price he or she wants. FGD Debra Camp, April 2018.

Others, however, feel that the operator is more powerful ("the operator decides how much he wants to pay") and that the law is on his side. The latter is often deliberately used as an institutional power resource to create statutory legitimacy.

One of the timber operators also mobilized socioeconomic power resources to compete with illegal loggers. By paying farmers extra money as an incentive to care for trees logged, but not yet loaded, he offered a competitive price compared to chainsaw millers who only pay for a felled tree.

Social capital as a power resource

Social power resources are mobilized in various ways through connectedness in groups and networks. Community members thereby rely primarily on bonding social capital. In addition to family and community bonds, several community social groups exist such as "Peace and Love" and "Odo ne kruye kuo" (Love and Unity), which are responsible for supporting community members during marriage, sickness, or a funeral of family member or relative. Bonding social capital is also reflected in the noboa practice, which is mutual help or common labor on farm land.

Respondents from both villages indicated that there are no or hardly any cooperations or alliances with other communities (bridging capital), and relations with outsiders (linking capital) are limited as well. Several nongovernmental organizations and donor organizations are active in the district in areas such as water and sanitation (sinking boreholes), education, health, and children rights (advocacy against child labor). Theoretically, these could help create linking social capital, but their presence is generally too brief, focused on short-term projects, and isolated from the wider institutional landscape to be able to perform such a role (AMDA 2014). Similarly, links exist between cocoa farmers and purchasing clerks of licensed cocoa buying companies, but these hardly ever lead to links further down the chain (Deans et al. 2018). Some linking capital exists through hybrid organizations that merge customary community structures with statutory ones. An example is the Community Biodiversity Advisory Group created by the FC to involve community members in clearing the boundaries of forest reserves and in serving as a watchdog against illegal activities in the forest. Basically, however, farmers rely mainly on bonding social capital in their negotiations with outside actors.

Customary governing structures play an important role in the strong connectedness and bonding capital within Ashanti villages. Communities are governed by traditional councils that belong to stools. These councils are made up of the local chiefs (Odikro or "owner of the village"); the queen mothers (Obaapanyin, who can be the chief's mother, his mother's sister, sister, a mother's sister's daughter, or a sister's daughter; Kendie and Guri 2006); and the council of elders, consisting of clan heads (Abusaupanyim) and subchiefs. The local chiefs are caretakers of stool lands and responsible for the allocation of lands, collection of land rents, and settling disputes on land issues in their domain. The councils are also in charge of general community welfare such as community development projects and communal labor. In Awisasu, the two chiefs and their elders collaborate to ensure harmony within the community.

For timber operators, the chief and elders are the primary entry point to negotiate access to timber resources. Although the operators have a permit from the FC, for peaceful cooperation to occur, they need to respect traditional authorities, customs, and norms such as meeting with the chiefs and elders prior to starting the operation.

During a meeting with the Chief, elders, district assemblywomen, six unit committee members, and two FSD officials, I informed the Chief and his elders about the 5\% stumpage fee due to the community. - Interview with timber operator \#1, April 2018.

Such negotiations may remain outside the purview of other community members, who are not involved in the negotiations but informed afterwards, confirming the hierarchical nature of customary governance structures (Derkyi 2012).

We are not involved in the negotiations. It is done by the Chief and his elders as well as the assemblywomen and some Unit Committee members. (...) Later the Chief and his elders assembled the community to inform us about the SRA deal and the money due to the community. The purpose was to decide on the use of the GCH 2000, to which the entire community agreed. Although everyone is happy with the outcome, we had no power to decide on the SRA deals. - FGD Debra Camp, May 2018.

Sometimes this situation leads to disagreement.

They just proceed with the majority view since they exceed the minority. The majority decided to build a whole classroom block, but the minority argued that the $S R A$ money was not enough to complete it. Now the structure remains unfinished. So the minority view is not always considered in this community. - FGD in Debra Camp, April 2018.

The timber operator active in Awisasu between 2009 and 2015 also created a kind of corporate network as a power resource. $\mathrm{He}$ appointed a local tree hunter tasked with identifying harvestable timber trees and negotiating compensation and incentive payments with the farmers. The operator left these negotiations entirely to the local tree hunter, thus capitalizing on strong social ties that play an important role in the negotiations.

At the onset of the operation, I established a network not only with the chiefs and elders but also with the youths in the community by providing some with employment. I also employed one of the youngsters as my spokesperson to communicate and engage in dialogue with farmers from his own village, so that I could make use of existing social ties. - Interview with timber operator \#2, May 2018.

This connectedness based on social ties became evident in the expression "He is a child of ours." In a small village like Awisasu, the tree hunter could simultaneously be the son, nephew, grandson, or neighbor of the inhabitants, and these ties helped create trust and thus facilitated conflict-free negotiations and cooperation. However, the conclusion that employing a local tree 
hunter and mobilizing bonding social capital is conducive to a conflict-free scenario (Derkyi 2012) was somewhat premature, as recent interviews revealed.

We have a problem with the tree hunter's ill-mannered behavior. Some farmers' trees were logged without their permission during the night. - FGD Awisasu, April 2018.

My sister's farmland had some trees. The tree hunter came to log them and said he would inform the timber contractor to pay. But she hasn't heard from him since.FGD Awisasu, April 2018.

These quotations illustrate that trustworthiness and reciprocity also determine the outcome of the negotiations. The timber operator previously active in Awisasu was welcome again because "he abided by our rules and the deals that we made" and proved to be trustworthy because "he paid as agreed" (community meeting Awisasu, 2009). However, a scenario of peaceful SRA negotiation and anticipated cooperation may transform into a conflict arena if the trust is breached.

Respect for local norms and values is another key determinant in the outcome of negotiations. In the interviews and focus groups, recurring reference was made to norms such as "love and unity" and "peaceful cooperation," the latter by both timber operators and community members. Another statement was, "he abided by our rules," as was reflected in the timber operator following local customs in dealing with traditional authorities.

\section{Orientational power resources}

Four of the orientational power resources distinguished by Marfo (2006) were identified: strategic framing, cultural beliefs and symbols, information and knowledge, and threats and sanctions. A recurring use of strategic framing was the notion of peaceful cooperation on both sides, based partly on opportunism (undisturbed operations for the timber operators and economic benefits for the communities), and as such, narrowly related to the use of socioeconomic power resources. However, we also observed conformism:

We were not happy with the price paid to us, but we have no option but to accept it. - Interview with elder, Awisasu, April 2018.

Cultural symbols are sometimes also used to seal the negotiations.

We negotiated the 5\% stumpage fee and then requested for a sheep to be slaughtered as a sacrifice to the river gods to ask permission from the gods for a peaceful logging operation. - FGD Awisasu, April 2018.

More generally, timber operators are expected to respect local taboos such as not harvesting on certain days or not harvesting saplings of economically or culturally important trees or herbs such as Esa (Celtis mildbreadi) and Odum (Milicia excelsa) (Derkyi 2012).

Knowledge and information were mobilized as power resources, first, by hiring a tree hunter for his local knowledge.

The tree hunter knows the farms and the tree species to be harvested, and also knows the community well. Interview with timber contractor \#1, April 2018.
Second, the absence of knowledge and information can be used to manipulate community members and farmers. In Awisasu, community members would have preferred an SRA in kind for the building of a school, public toilet, road, or street light. Instead, the $5 \%$ stumpage fee was paid in cash, suggesting that this was a new rule of the government. The existence of such a rule was, however, contradicted by staff of the FC in Kumasi (Valerie Fumey Nassah, personal communication, June 2018).

We couldn't say our wish, but it was rather imposed on us. The FSD officials and timber operator made us believe that this is the new arrangement from the FC. We were told that it's an order from the government. - FGD Awisasu, April 2018.

Third, information provision about upcoming timber operations is often deficient. Prior to the timber felling process, FSD range supervisors should visit the village to inform the inhabitants about the allocation of a permit to a timber contractor, the SRA, and crop damage compensation arrangements. Trees are then marked that qualify for harvesting. In Awisasu, the farmers confirmed that this had happened in 2009, suggesting that this is another key factor in preventing conflicts. Although the interviewed FSD officials confirmed the importance of more direct contacts with the communities and farmers to explain properly the procedures, harvesting plans, and farmers affected, in many cases, this is impossible because of a lack of staff and logistical resources (car, fuel). In those cases, information is limited to a 21-day notification pasted at the District FSD and District Assembly offices, and is usually unnoted by the farmers affected.

Farmers are well aware of the fact that a lack of knowledge of their rights and responsibilities is a disadvantage.

The FSD should make timber rules known to forest fringe communities by spreading their rules through radio stations, so that we know and abide to them, and to prevent conflicts. - FSD Awisasu, April 2018.

Finally, threats and sanctions were used as orientational power resources. A subtle sanction is the loss of reputation, of which one of the timber operators was well aware.

There is the need to monitor the activities of the [tree] hunters to avoid tarnishing our names and relationship with the entire community, especially when it comes to payment of compensation fees to the farmers. - Interview with timber operator \#2, May 2018.

Also, laws and regulations may be used as a threat, as will be shown next.

\section{Institutional power resources}

Institutional power resources are used to create legal legitimacy referring to either statutory or customary laws and regulations (Marfo 2006). These power resources are primarily mobilized by the FC and timber operators, affecting both the timber operators' and communities' position in the negotiation process. For the timber operator, the law provides statutory legitimacy to his deals.

On the SRA, I only abide by the Forestry rules, which says $5 \%$ of the stumpage fee is due to the community. Interview with timber operator \#2, April 2018. 
On the part of the community, statutory legitimacy may constitute a threat that leads to conformism, knowing that the space for negotiation is restricted because of legal provisions.

When the timber contractors come, they normally say that the tree doesn't belong to us but rather the crops on the land. They instill fear in us because of the permit they have from the FSD. - FGD Awisasu, April 2018.

We had no power to decide on the SRA deals. Since it was from the Forest Services Division we adhered to it. Nana (the chief) said [that] during the era of Dr. Kwame Nkrumah, it was announced that each tree on an individual's farm belongs to the Government. We just agreed with the contractor and the FSD officials since we were told the rules concerning SRA are coming from the government. - FGD Debra Camp, April 2018.

This power of law (statutory legitimacy), together with the customary legitimacy given to negotiating exclusively with traditional authorities, may contribute to feelings of unfairness and not being heard.

We didn't want it that way. We were expecting that they ask us what we want and not decide for us. (...) The negotiation was unfair since we were expecting that the whole community would be involved in the negotiation process. - FGD Debra Camp, April 2018.

This situation may create a delicate balance between conflict and cooperation, with subtle and open forms of resistance emerging, as illustrated next.

\section{Patterns of interaction}

Conflict issues

Conflicts over timber resources in off-reserve areas occur mainly between legal timber operators and illegal chainsaw loggers, between timber operators and local communities, and between illegal chainsaw loggers and public authorities (FC, police, and the judiciary). They mainly revolve around (1) the absence of benefit-sharing arrangements for farmers who nurture timber trees on their land, (2) inadequate compensation of crop damage and nonexistent guidelines to that end, and (3) failing SRA negotiations (Derkyi 2012, Derkyi et al. 2014, see also Amanor 2005, Marfo 2006, Marfo et al. 2006, 2012, Hansen and Treue 2009, Kyereh et al. 2009, Marfo and Schanz 2009, Hansen 2011). Despite legal provisions that establish the right to prior consent and payment for logging damage to crops, compliance is low, with $80 \%$ of off-reserve logging operations being carried out without farmers' prior consent, and nearly $50 \%$ of compensation payments either not agreed upon or unfulfilled (Hansen 2011). Focus group discussions with timber operators and communities confirmed the conflict issues mentioned in the literature. The timber operators blame the FC for not properly informing the communities about the SRA and compensation arrangements. In their opinion, this paves the way for illegal chainsaw operators, who are invited by farmers to fell trees on lands given to contractors because it allows the farmers to gain more directly from the trees on their farmland. As a result, farmers destroy seedlings and young timber trees that are not of use to them to prevent entrance of timber operators, or they sell trees to illegal chainsaw operators for a better deal (Amanor 2005, Marfo 2006, Bani 2016).
Interviews with farmers revealed the reasons for these and other forms of resistance. First, from experience, they know that timber contractors destroy the crops when harvesting the timber trees, while often not paying crop damage compensation as required. Second, sometimes farmers are not even informed that the trees on their farmlands or fallow lands have been given out to a timber contractor. Some timber operators log timber on farmlands without the farmers' consent during the night or their absence. Only if these farmers meet the contractor in person, they have the opportunity to negotiate. Third, they receive no direct benefits from timber trees unless sold to an illegal timber operator who pays them to remain silent. Fourth, farmers are not paid for tending the trees. They protect some timber trees such as Ceiba pentandra for improving soil fertility and providing shade for them to rest when tired during farming, or emire (Terminalia ivorensis) and ofram (Terminalia superba) for functioning as shade trees for cocoa. Other examples of tree tending, not mentioned by the respondents in this study, include wawa (Triplochiton scleroxylon) because of its high value due to scarcity, and African mahogany (Khaya ivorensis) because of its medicinal value (Bani 2016). However, there is no operational guideline that recognizes this tree tending as forest management, leaving farmers without a share in the stumpage fees.

Although the two study communities were not involved in serious conflicts during the fieldwork periods, an open conflict emerged in Awisasu in 2016, when a contractor breached the trust created after successful SRA negotiations by liaising with one of Ghana's largest timber operators.

The community signed a contract with Madam Beatrice. When she came to sign she did not inform us that she would bring another timber contractor; a relative of hers. We were furious and concerned that the big logging machines and vehicles would harm our road. Early in the morning, we made a barricade in the middle of the road to prevent the vehicle from going. They weren't able to go. They quickly called Madam Beatrice to inform her about the incident. The next day, we were playing games like oware and ludo at the usual place under a tree. Suddenly some of us saw a troop of soldiers coming towards our direction. Most of us fled away to the bush. One guy was left behind (...); he was beaten up and taken away to Nkawie Police Station. The community paid 1000 Ghana cedis to bail him. - Interview with youngster from Awisasu, April 2018 (name of the timber contractor changed for privacy reasons).

\section{Conflict management}

The use of violence as a conflict management strategy as described above tends to be an exception. It shows, however, how social capital is mobilized in such a case: local networks based on bonding social capital among local youth for collective action, and the timber contractor's external networks to end the conflict by force. In the words of one community member,

Madam Beatrice's representative informed her of the barricade the youth had made to prevent the movement of the vehicle loaded with logs. Because she has external networks, within a twinkle of a moment, some military 
personnel came to harass and arrest one of the youth in the community. - FGD Awisasu, April 2018.

The preferred conflict management strategies are avoidance and mediation, as illustrated by frequent use of the term "peaceful cooperation" and the following statement.

In our community, we resolve misunderstandings amicably with the help of the Chief and the elders. There is peace and love among us. - FGD Awisasu, April 2018.

Both parties were inclined to avoid conflicts, out of either pragmatism ("We all benefit from the SRA money, and individual farmers benefit from the compensation of crop damage") or conformation ("These are rules from the government"). This response is largely because of the prospect of material benefits: timber for the operator, and material benefits for the community and farmers.

Often witnesses are used to prevent conflicts, as in the case of SRA negotiations, where representatives of the Unit Committee (the lowest level of decentralized government), District Assembly, or FSD are often present. No such witnesses are present in negotiations over compensation payments with individual farmers.

Where disagreement emerges, mediation is the most commonly employed conflict mitigation strategy, with traditional authorities playing an important role.

In case of disagreement between a timber contractor and individual farmers, the community comes together to solve it, using the Chief as the mediator. - FGD Debra Camp, April 2018.

Also, the FSD of the FC mediates in SRA negotiations. However, in negotiations between timber contractors and individual farmers, the FSD only mediates when an agreement is not reached and one of the parties sends a petition letter.

In the case of a crop damage compensation conflict, we bring the two parties together and solve the conflict. Sometimes, we find that the amount the farmer is asking is too much; other times, we call on the timber operator to accept his mistakes and pay the farmers to their satisfaction. We stand as the mediator. - Interview with FSD Official, Nkawie Forest District, April 2018.

\section{DISCUSSION}

Several power resources (Marfo 2006) play a role in the interactions between timber operators, communities, and farmers to negotiate access to timber and its benefits. Initially, socioeconomic power resources dominate the negotiations, which usually start when timber operators sit together with traditional authorities to discuss the SRA arrangement. At this stage, all parties tend to favor peaceful cooperation, seeing that it guarantees undisturbed operations and access to timber for the harvester and material benefits for the community, including youth employment. Community leaders and farmers are willing to maintain a good relationship with a timber operator who respects their rights, plays the rules of the game, and pays fair compensation for crop damage.

Social capital (connectedness, trust, rules and norms, and reciprocity) does, however, play a role right from the first encounters and was mobilized as a social power resource by timber operators to avoid conflicts experienced in the past. Respecting local norms is key to guaranteeing peaceful cooperation, a norm in itself. It entails applying the customary mores in dealing with traditional authorities and building traditional networks (Marfo 2006). It also implies respect for local taboos that prohibit interfering with the forest, water streams, or specific plant or animal species on a particular day of the week or during a specific period (see Berkes et al. 2000, Colding and Folke 2001, and Derkyi 2012 for more details). Local norms are intertwined with other dimensions of social capital such as trustworthiness created by properly documenting the negotiations regarding damage compensation and paying promptly (abiding with the rules, complying with agreements, timely payment). Also, reciprocity (paying for tending trees felled but not yet loaded, fair compensation for crop damage) is decisive in whether interactions result in conflict or cooperation. Specific reciprocity or the "simultaneous exchanges of items" (Pretty and Ward 2001:211) prevailed in this respect: the contractor had access to trees while villagers enjoyed some investment in community development through the SRA, farmers received a payment for crops destroyed, and some youths gained access to employment. We found little evidence of diffuse reciprocity through which benefits can be returned at a later stage, other than the remark of the inhabitants of Awisasu that the timber operator would be welcome to come back in the future. Diffuse reciprocity is more common in the continuing relationship between cocoa farmers and purchasing clerks to whom they sell cocoa (Ataa-Asantewaa, personal communication, October 2017; see also Kooijmans 2016).

Mobilizing social capital also plays an important role once timber operations start. A solid customary governance system creates a strong sense of unity, common identity, belonging, and togetherness in Ghanaian communities (Owusu-Sarpong 2003). Examples of such connectedness are local groups such as Peace and Love and Odo ne kruye kue, whose members help each other when the need arises. This connectedness is further strengthened by strong religious connectedness, with $95 \%$ of the study communities actively practicing Christianity. By employing a local tree hunter who negotiates on their behalf, timber operators are able to capitalize on such strong local ties.

However, as Grischow (2008) has argued, the role of customary structures and bonding social capital in conflict management should not be idealized because it may lead to blindness to intracommunity differences and conflict. Group heterogeneity (e.g., in terms of cultural differences or differential endowments) often reflects power heterogeneity (Ballet et al. 2007). Also, Derkyi (2012) showed that the same customary governance structures that play an important role in conflict management in Ghana's high forest zone represent a hierarchical organization, often resulting in elite capture of timber benefits. Timber deals and SRA negotiations are commonly done by the chiefs and elders, and the chief's control over timber revenues is the rule rather than the exception, as evidenced by the saying "Royal takes it all" (Bani 2016:51). Amanor (2005:21,22) also criticized the lack of transparency regarding expenditure beyond "the upkeep of the stool" and noted that chiefs adhere to their "customary privilege to own timber resources and receive royalties." This lack of transparency relates to "the dark side of 
social capital," i.e., the exclusion and marginalization of others due to strong ties among the elite (Ostrom 1999, McDougall and Banjade 2015).

Nonexisting bridging social capital and weak linking capital place timber operators in an advantaged negotiation position. Linking social capital with the FC exists through hybrid governing structures such as the Community Biodiversity Advisory Groups and Community Forestry Committees, but community members consider the FC as an ally of timber operators rather than an agency that protects their rights ("they instill fear in us"). This situation does not mean that community members are passive actors; examples of hidden and open resistance were found in both this study and the literature (e.g., Kyereh et al. 2009, Oduro et al. 2018).

Orientational and institutional power resources are strongly linked to socioeconomic and social power resources. Strategic framing is mainly used in relation to material benefits (socioeconomic power resources), whereas cultural framing and beliefs are embedded in local norms and values (social power resources). Timber operators mobilize orientational power resources such as local knowledge and information about rules and regulations, or the absence of such knowledge among farmers, as a strategy to gain access to timber resources. Similarly, they use laws and statutory legitimacy as institutional power resources to the same end. This situation suggests a complex interplay of different power resources in the interactions between timber operators, communities, and farmers, as was also found by Marfo (2006).

Mediation by Chiefs plays an important role in conflict management. Such evidence has also been provided by Sanginga et al. (2007), who found that traditional authorities and local women and farmer groups can play an important role in intracommunity conflict resolution. However, this capacity was much lower in supracommunity conflicts that involve conflicts with more powerful external actors at higher levels of scale. Ratner et al. (2013) link this to the distinction between bonding, bridging, and linking capital, with bonding social capital being most effective in preventing intracommunity conflicts, bridging capital most effective in preventing intercommunity conflicts, and linking capital most effective in preventing supracommunity conflicts. In the Awisasu case, bonding social capital played a major role. By staying at a distance and leaving negotiations to a local tree hunter, supracommunity conflicts could be avoided and redirected to the intracommunity level, where social capital was strongest. This result may explain why, in this case, conflicts between the timber operator and the community and its inhabitants were avoided, whereas timber exploitation in similar contexts often leads to conflicts (e.g., Amanor 2005, Marfo 2006, Marfo et al. 2006, 2012, Hansen and Treue 2009, Kyereh et al. 2009, Marfo and Schanz 2009, Hansen 2011).

\section{CONCLUSION}

Ghana's off-reserve landscapes generate timber revenues for individual actors and the country as a whole and are a major source of agricultural livelihoods for local people. Inequitable sharing of timber revenues and unfair compensation for tree tending and crop damage has turned the area into a contested battlefield. We analyzed this battlefield as an action arena (Ratner et al. 2013) in which interactions between actors are shaped through a complex mix of power resources: socioeconomic, social, orientational, and institutional (Marfo 2006). We expanded the social power resources with dimensions of social capital with a view to revisiting and testing the conclusion of earlier work (Derkyi 2012) that mobilizing bonding social capital may result in a scenario of cooperation.

We revealed how social capital has been used among other power resources to negotiate access to timber and its benefits in Ghana's off-reserve areas. We did so with a view to shedding light on processes that lead to conflict or cooperation. Our conclusions in this respect are fourfold. First, conflicts do not only emerge because of disputes over resource access and benefits, as most literature on natural resource conflicts suggests. Second, how social capital is mobilized is a key factor in explaining whether interactions between actors lead to conflict or cooperation. Although different kinds of networks (traditional, local, corporate) play a role, we argue that cultural norms and trustworthiness, in particular, play a more important role than is generally acknowledged. Third, poor information and knowledge of rules and regulations among forest fringe communities and farmers is used as a power resource, suggesting that more can be done to create awareness and transparency about rights and responsibilities. Fourth, the factors most conducive to the peaceful cooperation that all parties, in principle, desire include: (1) respect for local norms and rules; (2) trustworthiness in complying with the agreements made, including prompt payment; (3) transparency in the negotiation process; (4) a feeling among all community members that they have a say in the arrangements; and (5) a fair price for tending the trees and to compensate for the crop damage incurred.

Our findings are not only relevant to the theory, policy, and practice of forest and tree resource management. Newly emerging forest regimes such as "Reducing emissions from deforestation and forest degradation" (known as REDD+) and initiatives such as "Forest, law enforcement, governance, and trade" (known as FLEGT), aimed at combatting illegal logging and improving forest governance, go together with increasingly complex stakeholder configurations and conflicting interests (Wiersum et al. 2013). The same applies to the trend toward integrated governance of multifunctional landscapes. These integrated landscape approaches advocate multistakeholder negotiations of trade-offs between different land uses, with a view to reconciling multiple aims such as climate resilience, food security, sustainable livelihoods, and forest and biodiversity conservation (Sayer et al. 2013, Freeman et al. 2015, Reed et al. 2017, Ros-Tonen et al. 2018). Further research could illuminate how social capital and other power resources in such multistakeholder settings can help mitigate conflicts and achieve negotiated outcomes.

Responses to this article can be read online at: http://www.ecologyandsociety.org/issues/responses. php/10408

\section{Acknowledgments:}

This paper is a spin-off of the Inclusive Value Chain Collaboration project financed by WOTRO Science for Global Development of 
The Netherlands Organization for Scientific Research (NWO; project W08.250.2013.122) and an earlier collaborative effort with Tropenbos International Ghana. We thank the inhabitants of Awisasu and Debra Camp and other interviewees for their willingness to share their knowledge and experiences. We also thank Akua Boatemaa Danquah and Linda Adinkra Forson for assistance in data collection, and Kwabena Asubonteng for drawing the map in Fig. 2. We are grateful to Eleonor Fisher for her encouragement during the writing process, and two anonymous reviewers for their constructive comments on an earlier version of this paper.

\section{LITERATURE CITED}

Akpalu, W., and P. J. Parks. 2007. Natural resource use conflict: gold mining in tropical rainforest in Ghana. Environment and Development Economics 12(1):55-72. http://dx.doi.org/10.1017/ $\underline{\mathrm{S} 1355770 \mathrm{X} 0600338 \mathrm{X}}$

Amanor, K. S. 2005. Equity in forest benefit sharing and poverty alleviation. Pages 15-23 in K. S. Nketiah, J. A. S. Ameyaw, and B. Owusu Jr., editors. Equity in forest benefit sharing: stakeholders' views. Tropenbos International, Wageningen, The Netherlands. [online] URL: http://www.tropenbos.org/file.php/217/benefitsharingsmall. pdf

Atwima Mponua District Assembly (AMDA). 2014. District medium-term development plan: MTDP (2014-2017). Local Government Service Secretariat, Accra, Ghana. [online] URL: https://new-ndpc-static1.s3.amazonaws.com/CACHES/ PUBLICATIONS/2016/04/04/AR Atwima+Mponua 2014-2017+ DMTDP.pdf

Ballet, J., N. Sirven, and M. Requiers-Desjardins. 2007. Social capital and natural resource management: a critical perspective. Journal of Environment and Development 16(4):355-374. http://dx. doi.org/10.1177/1070496507310740

Bani, K. B. 2016. Farmers' willingness to pay for environmental services on farmlands and implications for resource governance in Sene East District, Ghana. Thesis. Kwame Nkrumah University of Science and Technology, Kumasi, Ghana. [online] URL: http:// ir.knust.edu.gh/bitstream/123456789/9116/1/BANI\%20Kwasi\% 20Benjamin.pdf

Barnes-Mauthe, M., K. L. L. Oleson, L. M. Brander, B. Zafindrasilivonona, T. A. Oliver, and P. van Beukering. 2015. Social capital as an ecosystem service: evidence from a locally managed marine area. Ecosystem Services 16:283-293. http://dx. doi.org/10.1016/j.ecoser.2014.10.009

Bavinck, M., E. Mostert, and L. Pellegrini. 2014. Introduction. Pages 1-11 in M. Bavinck, L. Pellegrini, and E. Mostert, editors. Conflicts over natural resources in the global South: conceptual approaches. CRC Press, Boca Raton, Florida, USA. http://dx.doi. org/10.1201/b16498-2

Berkes, F., J. Colding, and C. Folke 2000. Rediscovery of traditional ecological knowledge as adaptive management. Ecological Applications 10(5):1251-1262. http://dx.doi. org/10.1890/1051-0761(2000)010[1251:ROTEKA]2.0.CO;2

Bih, F. 2006. Assessment methods for non-timber forest products in off-reserve forests: case study of Goaso district, Ghana. Dissertation. University of Freiburg, Freiburg, Germany. [online]
URL: https://www.freidok.uni-freiburg.de/fedora/objects/freidok:2847/ datastreams/FILE1/content

Bodin, Ö., and B. I. Crona. 2008. Management of natural resources at the community level: exploring the role of social capital and leadership in a rural fishing community. World Development 36(12):2763-2779. http://dx.doi.org/10.1016/j. worlddev.2007.12.002

Bodin, Ö., and B. I. Crona. 2009. The role of social networks in natural resource governance: What relational patterns make a difference? Global Environmental Change 19(3):366-374. https:// doi.org/10.1016/j.gloenvcha.2009.05.002

Buckles, D., and G. Rusnak. 1999. Conflict and collaboration in natural resource management. Pages 3-10 in D. Buckles, editor. Cultivating peace: conflict and collaboration in natural resource management. International Development Research Centre, Ottawa, Canada, and World Bank Institute, Washington, D.C., USA.

Colding, J., and C. Folke 2001. Social taboos: "invisible" systems of local resource management and biological conservation. Ecological Applications 11(2):584-600. http://dx.doi.org/10.2307/3060911

Coleman, J. S. 1998. Social capital in the creation of human capital. American Journal of Sociology 94:S95-S120. [online] URL: https://www.jstor.org/stable/2780243

Deans, H., M. A. F. Ros-Tonen, and M. Derkyi. 2018. Advanced value chain collaboration in Ghana's cocoa sector: an entry point for integrated landscape approaches? Environmental Management 62(1):143-156. http://dx.doi.org/10.1007/s00267-017-0863-y

Derkyi, M. A. A. 2012. Fighting over forest: interactive governance of conflicts over forest and tree resources in Ghana's high forest zone. African Studies Collection 41. African Studies Centre, Leiden, The Netherlands. [online] URL: http://www.tropenbos. org/file.php/1159/mercy-derkyi thesis.pdf

Derkyi, M., M. A. F. Ros-Tonen, B. Kyereh, and T. Dietz. 2014. Fighting over forest: toward a shared analysis of livelihood conflicts and conflict management in Ghana. Society and Natural Resources 27(3):281-298. https://doi.org/10.1080/08941920.2013.861550

Eckerberg, K., and C. Sandström. 2013. Forest conflicts: a growing research field. Forest Policy and Economics 33:3-7. http:// dx.doi.org/10.1016/j.forpol.2013.05.001

Forestry Commission. 1998. Manuals of procedure for forest resource management planning in the high forest zone of Ghana. Ghana Forestry Commission, Accra, Ghana. [online] URL: https://www.fcghana.org/assets/file/Publications/Manuals/MOP.pdf

Freeman, O. E., L. A. Duguma, and P. A. Minang. 2015. Operationalizing the integrated landscape approach in practice. Ecology and Society 20(1):24. http://dx.doi.org/10.5751/ ES-07175-200124

Grischow, J. D. 2008. Rural 'community', chiefs and social capital: the case of southern Ghana. Journal of Agrarian Change 8 (1):64-93. http://dx.doi.org/10.1111/j.1471-0366.2007.00163.x

Gritten, D., B. Mola-Yudego, C. Delgado-Matas, and J. Kortelainen. 2013. A quantitative review of the representation of forest conflicts across the world: resource periphery and emerging 
patterns. Forest Policy and Economics 33:11-20. http://dx.doi. org/10.1016/j.forpol.2012.06.008

Hansen, C. P. 2011. Forest law compliance and enforcement: the case of on-farm timber extraction in Ghana. Journal of Environmental Management 92(3):575-586. http://dx.doi.org/10.1016/ j.jenvman.2010.09.021

Hansen, C. P., and T. Treue. 2009. The sharing of financial benefits from timber trees in Ghana: issues of equity and economic incentives with emphasis on the off-reserve situation. Pages 31-45 in B. Kyereh, K. Okae, and C. P. Hansen, editors. Strengthening off-reserve timber management in Ghana. Tropenbos InternationalGhana, Kumasi, Ghana. [online] URL: http://www.tropenbos. org/file.php/40/final $\% 20$ proceedings $\% 207$.pdf

Hellin, J., B. D. Ratner, R. Meinzen-Dick, and S. Lopez-Ridaura. 2018. Increasing social-ecological resilience within small-scale agriculture in conflict-affected Guatemala. Ecology and Society 23(3):5. https://doi.org/10.5751/ES-10250-230305

Hermens, J. 1999. "We are poor people, they do not care about us": A case study on gender, sources of power and benefit from development projects in a North Indian village. Nijmegen University Press, Nijmegen, The Netherlands.

Hirons, M. A. 2014. Mining, forests and land-use conflict: the case of Ghana. Dissertation. University of Reading, Reading, UK.

Kasanga, K. R. 2003. Current land policy issues in Ghana. Pages 141-154 in P. Groppo, editor. Land reform: land settlement and cooperatives. Food and Agriculture Organization, Rome, Italy. [online] URL: http://www.fao.org/docrep/006/y5026e/y5026e0a. $\underline{\mathrm{htm} \# \mathrm{bm} 10}$

Kendie, S. B., and B. Y. Guri. 2006. Indigenous institutions as partners for agriculture and natural resource management. Pages 106-128 in D. Millar, S. B. Kendie, A. A. Apusigah, and B. Haverkort, editors. African knowledges and sciences: understanding and supporting ways of knowing in sub-Saharan Africa. ETC/ Compas, Leusden, The Netherlands. [online] URL: https://www. bibalex.org/Search4Dev/files/416877/362463.pdf

Kooijmans, L. 2016. Space for deliberation in Ghana's cocoa sector. Exploring how smallholder cocoa farmers pursue their aspirations by navigating their networks, built around locally embedded valuechain collaborations with and without involvement of certification programmes. Thesis. University of Amsterdam, Amsterdam, The Netherlands. [online] URL: https://inclusivevcc.files.wordpress. com/2015/07/ids thesis_- space_for_deliberation_in_ghanas_cocoa sector - lars kooijmans.pdf

Kyereh, B., K. Okae, and C. P. Hansen, editors. 2009. Strengthening off-reserve timber management in Ghana. Tropenbos International-Ghana, Kumasi, Ghana. [online] URL: http://www.tropenbos.org/file.php/40/final\%20proceedings $\% 207$. pdf

Leach, M., and O. Scoones, editors. 2015. Carbon conflicts and forest landscapes in Africa. Routledge, London, UK.

Lyon, F. 2000. Trust, networks and norms: the creation of social capital in agricultural economies in Ghana. World Development 28(54):663-681. https://doi.org/10.1016/S0305-750X(99)00146-1

Marfo, E. 2006. Powerful relations: the role of actor-empowerment in the management of natural resource conflict: a case of forest conflicts in Ghana. Dissertation. Wageningen University, Wageningen, The Netherlands. [online] URL: http://edepot.wur. $\underline{n 1 / 43182}$

Marfo, E. 2010. Chainsaw milling in Ghana: context, drivers and impacts. Tropenbos International, Wageningen, The Netherlands. [online] URL: http://www.tropenbos.org/file.php/208/ chainsaw milling in ghana marfo2010.pdf

Marfo, E., E. Acheampong, and E. Opuni-Frimpong. 2012. Fractured tenure, unaccountable authority, and benefit capture: constraints to improving community benefits under climate change mitigation schemes in Ghana. Conservation and Society 10(2):161-172. http://dx.doi.org/10.4103/0972-4923.97488

Marfo, E., E. Acheampong, C. Osae. 2006. An assessment of compliance with on-farm logging compensation payment regulations in Ghana: implications for policy interventions. Ghana Journal of Forestry 19(1):35-44. http://dx.doi.org/10.4314/ gif.v19i1.36909

Marfo, E., and H. Schanz. 2009. Managing logging compensation payment conflicts in Ghana: understanding actor-empowerment and implications for policy intervention. Land Use Policy 26 (3):619-629. http://dx.doi.org/10.1016/j.landusepol.2008.08.009

Marín, A., S. Gelcich, J. C. Castilla, and F. Berkes. 2012. Exploring social capital in Chile's coastal benthic comanagement system using a network approach. Ecology and Society 17(1):13. http:// dx.doi.org/10.5751/ES-04562-170113

McDougall, C., and M. R. Banjade. 2015. Social capital, conflict, and adaptive collaborative governance: exploring the dialectic. Ecology and Society 20(1):44. http://dx.doi.org/10.5751/ ES-07071-200144

Ministry of Lands and Natural Resources (MLNR). $2016 a$. Forestry development master plan (2016-2036). MLNR, Accra, Ghana. [online] URL: https://www.fcghana.org/userfiles/files/ MLNR/FDMP $\% 20$ Final $\% 20(2) . p d f$

Ministry of Lands and Natural Resources (MLNR). 2016b. Tree tenure and benefit sharing framework in Ghana. MLNR, Accra, Ghana. [online] URL: https://www.fcghana.org/userfiles/files/ MLNR/Tree $\% 20$ Tenure $\% 20$ final $\% 20(2)$.pdf

Mola-Yudego, B., and D. Gritten. 2010. Determining forest conflict hotspots according to academic and environmental groups. Forest Policy and Economics 12(8):575-580. http://dx.doi. org/10.1016/j.forpol.2010.07.004

Njuki, J. M., M. T. Mapila, S. Zingore, and R. Delve. 2008. The dynamics of social capital in influencing use of soil management options in the Chinyanja Triangle of southern Africa. Ecology and Society 13(2):9. http://dx.doi.org/10.5751/ES-02539-130209

Oduro, K. A., B. Arts, B. Kyereh, and G. Mohren. 2018. Farmers' motivations to plant and manage on-farm trees in Ghana. Smallscale Forestry 17:393 http://dx.doi.org/10.1007/s11842-018-9394-5

Ostrom, E. 1999. Social capital: a fad or fundamental concept? Pages 172-214 in P. Dasgupta and I. Sergeldin, editors. Social capital: a multi-faceted perspective. World Bank, Washington, D. C., USA. [online] URL: http://documents.worldbank.org/ curated/en/663341468174869302/pdf/multi-page.pdf 
Owusu-Sarpong, C. 2003. Setting the Ghanaian context of rural local government: traditional authority values. Pages 31-68 in D. I. Ray and P. S. Reddy, editors. Grassroots governance? Chiefs in Africa and the Afro-Caribbean. University of Calgary Press, Calgary, Canada.

Pretty, J. 2003. Social capital and the collective management of resources. Science 302(5652):1912-1914. http://dx.doi.org/10.1126/ science. 1090847

Pretty, J., and D. Smith. 2004. Social capital in biodiversity conservation and management. Conservation Biology 18 (3):631-638. http://dx.doi.org/10.1111/j.1523-1739.2004.00126.x

Pretty, J., and H. Ward. 2001. Social capital and the environment. World Development 29(2):209-227. http://dx.doi.org/10.1016/ S0305-750X(00)00098-X

Putnam, R.D. 1993. The prosperous community: social capital and public life. American Prospect 4(13):35-42. [online] URL: http://prospect.org/article/prosperous-community-social-capitaland-public-life

Putnam, R. D. 2000. Bowling alone: the collapse and revival of American community. Page 357 in Proceedings of the 2000 ACM conference on computer supported cooperative work. ACM, New York, New York, USA. http://dx.doi.org/10.1145/358916.361990

Ratner, B. D., R. Meinzen-Dick, C. May, and E. Haglund. 2013. Resource conflict, collective action, and resilience: an analytical framework. International Journal of the Commons 7(1):183-208. http://dx.doi.org/10.18352/ijc. 276

Reed, J., J. van Vianen, J. Barlow, and T. Sunderland. 2017. Have integrated landscape approaches reconciled societal and environmental issues in the tropics? Land Use Policy 63:481-492. https://doi.org/10.1016/j.landusepol.2017.02.021

Ros-Tonen, M. A. F., J. Reed, and T. Sunderland. 2018. From synergy to complexity: the trend toward integrated value chain and landscape governance. Environmental Management 62 (1):1-14. http://dx.doi.org/10.1007/s00267-018-1055-0

Sanginga, P. C., R. N. Kamugisha, and A. M. Martin. 2007. The dynamics of social capital and conflict management in multiple resource regimes: a case of the southwestern highlands of Uganda. Ecology and Society 12(1):6. http://dx.doi.org/10.5751/ ES-01847-120106

Sayer, J., T. Sunderland, J. Ghazoul, J.-L. Pfund, D. Sheil, E. Meijaard, M. Venter, A. K. Boedhihartono, M. Day, C. Garcia, C. van Oosten, and L. E. Buck. 2013. Ten principles for a landscape approach to reconciling agriculture, conservation, and other competing land uses. Proceedings of the National Academy of Sciences 110(21):8349-8356. http://dx.doi.org/10.1073/ pnas. 1210595110

Vedeld, P., A. Jumane, G. Wapalila, and A. Songorwa. 2012. Protected areas, poverty and conflicts: a livelihood case study of Mikumi National Park, Tanzania. Forest Policy and Economics 21:20-31. http://dx.doi.org/10.1016/j.forpol.2012.01.008

Wiersum, K. F., G. Lescuyer, K. S. Nketiah, and M. Wit. 2013. International forest governance regimes: reconciling concerns on timber legality and forest-based livelihoods. Forest Policy and Economics 32:1-5. http://dx.doi.org/10.1016/j.forpol.2013.04.011
Woolcock, M., and D. Narayan. 2000. Social capital: implications for development theory, research, and policy. World Bank Research Observer 15(2):225-249. http://dx.doi.org/10.1093/ wbro/15.2.225

Yasmi, Y., H. Schanz, and A. Salim. 2006. Manifestation of conflict escalation in natural resource management. Environmental Science and Policy 9(6):538-546. http://dx.doi.org/10.1016/j. envsci.2006.04.003 


\section{APPENDIX 1}

Actor

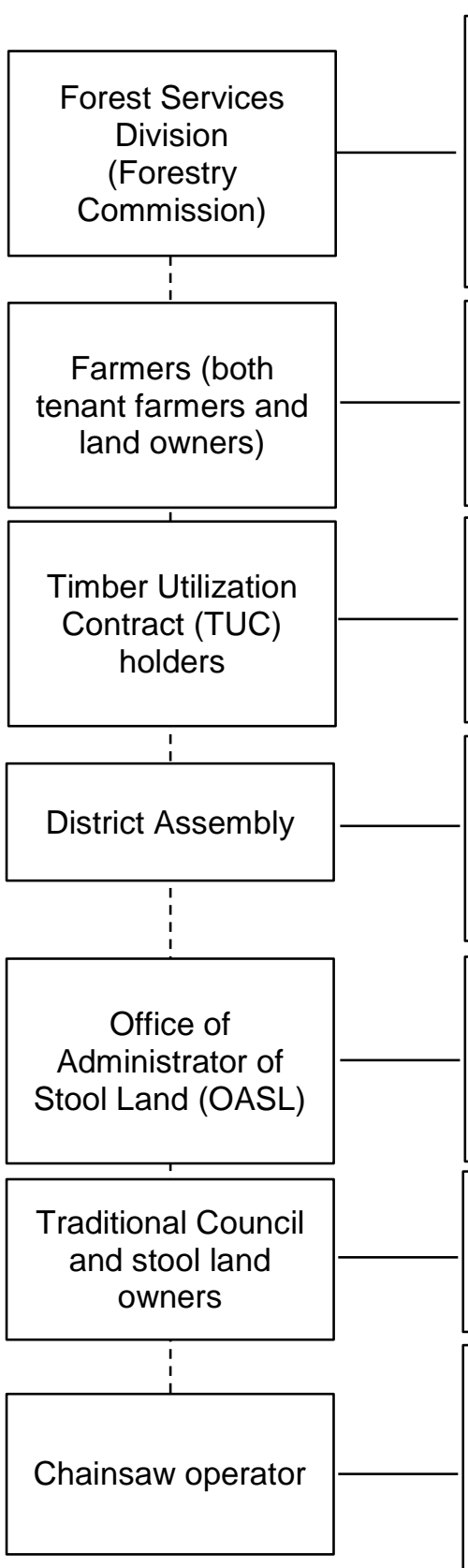

Actor's role in managing offreserve timber resources

Allocate timber felling rights to timber utilization contract (TUC) holders; occasionally mediating in crop damage/SRA disputes; no silvicultural management responsibilities

Tend and nurture saplings of economically valuable timber species when farming

Fell trees and pay stumpage for the harvested trees

Mediate in Social Responsibility Agreement (SRA) negotiation (in some districts)

Disburse timber royalties among beneficiaries

Providing access to farming land

No formal role; accesses timber resources illegally, sometimes pays a moderate compensation to the farmers
Actor's benefit from the timber resource/revenue

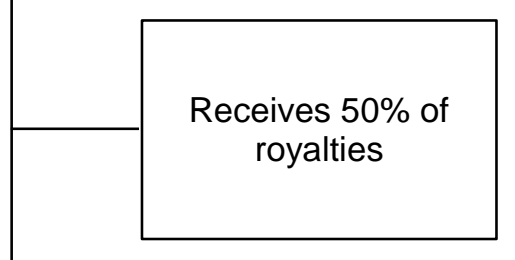

Fairly negotiated compensation (no fixed amount given)

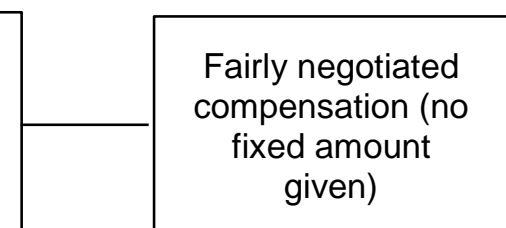

Access to timber trees

Receives $23.75 \%$ of royalties
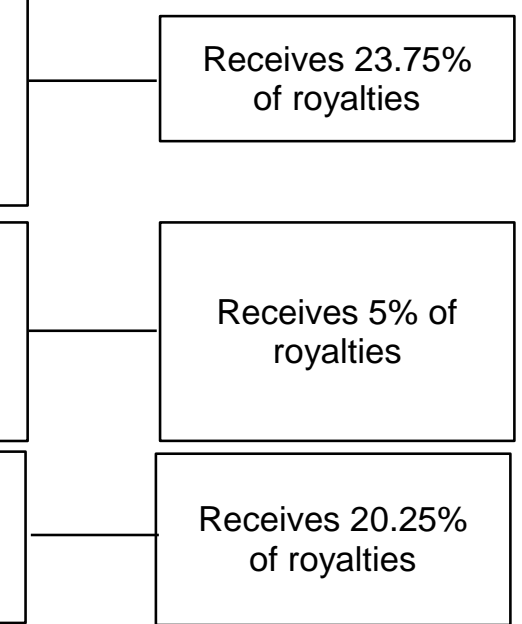

Free rider access to timber unless arrested

Figure 1. Distribution of off-reserve timber benefits over the actors involved 


\section{APPENDIX 2}

Table 1. Benefit-sharing arrangements for off-reserve timber trees in Ghana

Provision

Harvesting rights

Right of consent

Right to protection and damage compensation

Acknowledgement of ownership of planted trees

Contract area rent

Stumpage fee

Social responsibility arrangement (SRA)
Legal basis

Timber Resources Management Act, 1997, Act 547, section 1 and 2; Timber Resources Management (Amendment) Act, 2002 (Act 617), s.1(a).

Manual of Procedure for Forest Resource Management Planning in the High Forest Zone of Ghana, 1998, section 3

Manual of Procedure for Forest Resource Management Planning in the High Forest Zone of Ghana, 1998, section 4

Timber Resources Management (Amendment) Act, 2002 (Act 617), Section 4 of Act 547 amended; L.I. 1649 - Timber Resources Management Regulations, 1998.

Constitution 267 (2) (b) and (6) Timber Resources Management act, 1997, Act 547, section 8 (f) and section 15 (1) (a); Timber Resources Management Act 1997 LI 1649 (as amended by LI 1696 and LI 1721); regulation 27 and schedule 4.

Article 267 (6) of Constitution Timber Resources Management Act, 1997, Act 547, section 8 (e) and section 15 (1) (a)

Timber Resources Management Regulations 1998 LI 1649 (as amended by LI 1696 and LI 1721); regulation 21 and 25 and schedule 3.

Timber Resources Management Act, 1997, Act 547, section 3(3)(e)

Timber Resources Management Act 1997 LI 1649 (as amended
Rights

No person shall harvest timber from any land [...] unless he holds timber rights in the form of a timber utilization contract. Such rights can only be granted to timber operators officially registered as such and upon submission of a timber harvesting plan which includes an assessment of ecological damage and a plan for the SRA.

Sets out the consultation procedure required before timber rights can be assigned, involving District Assemblies, landowners and caretakers. Written consent is needed from the latter.

Stipulates that agreement is needed on timing of timber operations to minimize disruption of agricultural activities; that sacred sites should be respected; and agreement on payment for crop damage and tending trees be reached prior to felling the trees.

No timber rights can be granted for land with private timber plantations or timber owned by an individual or group. Owners do not need a TUC or permit to harvest these planted trees, but they do need a conveyance certificate to transport the logs.

The Forestry Commission (FC) and landowners are entitled to stumpage fees (royalties). The amount accruing to the FC to compensate it for forest management and timber regulations is not enshrined in law, but in practice $50 \%$ (Client Earth 2013). The Constitution determines that $10 \%$ of the remainder goes to the Office of Administration of Stool Lands to cover administrative expenses and $90 \%$ to the Stool $(25 \%)$, traditional authorities (chief) (20\%) and District Assembly (55\%). In case of private land ownership $100 \%$ of the contract area rent goes to the landowner.

Holders of Timber Utilization Contracts (TUCs) have to pay at least $5 \%$ of stumpage fee in the form of amenities, services or benefits to communities or inhabitants of timber utilization areas. 
by LI 16962002 and LI 1721 Includes provisions to negotiate 'Codes of 2003); Regulation 13(12)(b); conduct' between the timber contractor and Regulation 14(1)(v) local communities, with the District Forest Officer and District Chief Executive or their representative as arbiters.

Timber utilization L.I. 1649 - Timber Resources Possibility for a District Assembly, town permits (TUP) Management Regulations, 1998, committee, rural community group or nongovernmental organization to apply for harvesting a limited number of trees for social or community purposes. These trees cannot be sold or exported.

Sources: Forestry Commission (http://www.fcghana.org/library.php), Forest Watch Ghana 2006; Derkyi 2012; Client Earth 2013. 